\title{
Stem of musa paradisiacal (linn.) shows the inhibitory effect towards alpha amylase and alpha- glucosidase enzymes: antidiabetic activity
}

\begin{abstract}
The main objective of this study was to perform the in-vitro antidiabetic potential of stem of Musa paradisiacal (Linn.). Musa paradisiacal (MP) is commonly known banana. Its fruit is generally used as a dietary source. Various pharmacological activities have been investigated in leaves, fruits, and pulp of this plant. But very few activities and research have been done yet now on the stem of MP. We have used stem of MP to investigate its phytochemical constituents and pharmacological activity. Where, we were found various phytochemical constituents qualitatively and quantitatively like starch, sugar, flavonoids, phenolic compounds, proanthocyanidins, glycosides, fat, and alkaloids. Later, antidiabetic potential was investigated by using alpha amylase and alpha glucosidase inhibition method. The result concluded that that hydro alcoholic extract of MP exhibited inhibitory effect towards alpha amylase and alpha glucosidase enzymes. Due to this, the stem may used for the purpose of the better antidiabetic activity.
\end{abstract}

Keywords: musa paradisiacal, alpha-amylase, alpha- glucocidase, antidiabetic effect
Volume 2 Issue 2 - 2017

\author{
Sangeeta Verma,' Anil K Sahdev, ${ }^{2}$ Ajay S \\ Bisht, 'Vinit Raj ${ }^{2}$ \\ 'Himalayan Institute of Pharmacy \& Research, India \\ 2Department of Pharmaceutical Sciences, Babasaheb Bhimrao \\ Ambedkar University, India \\ "Both author have equal contribution
}

Correspondence: Vinit Raj, Department of Pharmaceutical Sciences, Babasaheb Bhimrao Ambedkar University,Vidya Vihar, Rae Bareli Road, Lucknow-226025, India,

Email raj.vinit24@gmail.com

Received: January 26, 2017 | Published: April 10, 2017

\section{Introduction}

Natural products are used to cure disease and illness with therapeutic properties from ancient time. Mineral, plant and animal products are the main sources of drugs. ${ }^{1} \mathrm{MP}$ mono herbaceous plant has the essential ingredient as medicinal which is belonging to Musaceae family. Musa paradisiacal has 2 genera and 42 of species. ${ }^{2}$ This plant is 9 to $10 \mathrm{~m}$ long. It is pseudo stem. Plant has a bunch of large and elongated of leaves approx 35 lengths and $0.5 \mathrm{~m}$ width Fruits are cylindrical oblong, 5 to $8 \mathrm{~cm}$ in length. ${ }^{3}$ This plant is mostly cultivated in India, America, and Australia, tropical region of Africa, Malaysia, and Southern America. ${ }^{4}$ MP has got a number of pharmacological activities such as anticonvulsant, antimicrobial, stones, anti stress etc. The major chemical constitutes were found like as tannin, saponin, sterol, triterpene, proanthocynidine in this plant. ${ }^{5-8}$ However, possession of broad range of activity, it attracts to researcher. The stem of MP has the potential chemical constituents. In this study, the aim of our study was to perform and evaluate the in vitro antidiabetic efficacy of stem of MP.

\section{Material and methods}

MP stem was collected from Gudrich Vikasnagar, Dehradun, Uttrakhand. The stems were cut into horizontally circular pieces and then dried. After that, grind into powder form and finally sieved to get uniform powder drug. Pharmacognostical and physicochemical evaluation were carried out from shade dried plant powder Physicochemical standardization methods including determination of moisture content (loss on drying), determination of total ash and acid insoluble ash, extractive values were carried out as per WHO recommendations and authentic procedures mention in Ayurvedic pharmacopeia of India. Further, we have estimated the total Sugar and total starch in plant, by taking dextrose and starch (soluble), respectively as a standard solution. Whereas, the total tannins were determined by using tannic acid as standard and gallic acid for the determination of total phenolics contents. For the determination of total flavonoids and total flavonols, Rutin was taken as a standard. Proanthocyanidins were estimated by using Catechin as a standard.

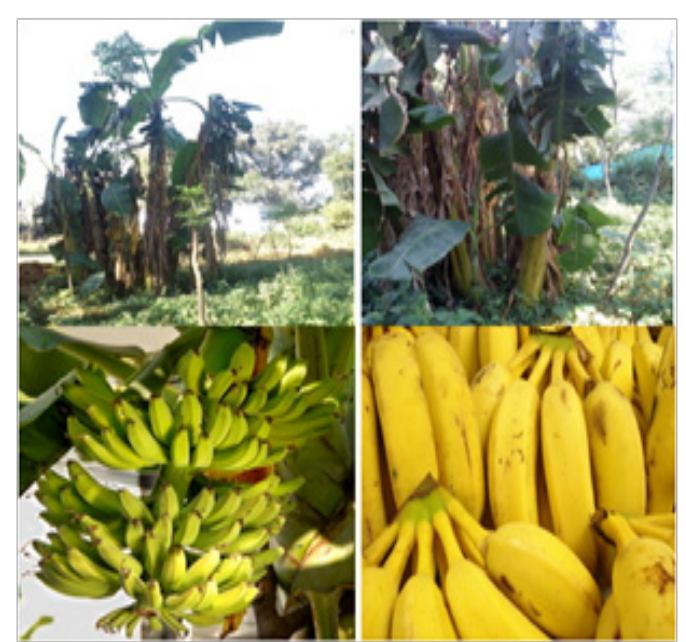

Figure I Showing different parts of Musa Paradisiaca

\section{Alpha - amylase inhibition}

Firstly, we have prepared the starch solution in the buffer and enzyme solution (alpha amylase in $100 \mathrm{ml}$ of dissent. water). After that, colorimetric solution was prepared through established protocol. Both control group and plant extract group (various concentration) was added into starch solution, respectively and left to react at 370C with alpha amylase. Amount of generated maltose was quantified due to reduction of 3,5-dinitro salicylic acid to 3-amino,5-nitro salicylic acid. This was measured by UV spectroscopy at $540 \mathrm{~nm}$. 


\section{Alpha - glucosidase inhibition}

Firstly, we prepared starch substrate; $0.2 \mathrm{M}$ tris buffer $\mathrm{pH} 8.0$ and plant extract with various concentrations and incubate for $5 \mathrm{~min}$ at $37^{\circ} \mathrm{C}$. After that, the reaction was initiated by adding $1 \mathrm{ml}$ of alphaglucosidase enzyme $(1 \mathrm{U} / \mathrm{ml})$, incubated for $40 \mathrm{~min}$ at $35^{\circ} \mathrm{C}$. Further the reaction was terminated by condition of $2 \mathrm{ml}$ of $6.0 \mathrm{NHCl}$ and Intensity of the color measured at $540 \mathrm{~nm}$.

\section{Calculation of $50 \%$ inhibitory concentration (IC50)}

The concentration of the extract required to scavenge $50 \%$ of the radicals (IC50) was calculated by using the percentage scavenging activities at five different concentrations of the extract.

Percentage inhibition (I \%) was calculated by I \%=(Ac-As) $/$ Ac $X$ 100

Table I Phytochemical screening of successive fraction from soxhlet, $(+)$ shows presence, and $(-)$ shows the absence of content of stem

\begin{tabular}{|c|c|c|}
\hline S.No. & Compound & Test \\
\hline \multirow[t]{3}{*}{1} & \multirow[t]{3}{*}{ Carbohydrates } & Molish' test \\
\hline & & Fehling's test \\
\hline & & Benedict's test \\
\hline \multirow[t]{2}{*}{2} & \multirow[t]{2}{*}{ Protein } & Biuret test \\
\hline & & Millon test \\
\hline 3 & Amino acids & Ninhydrin test \\
\hline 4 & Fats and oils & Solubility test with $c$ \\
\hline \multirow[t]{2}{*}{5} & \multirow[t]{2}{*}{ Flavonoids } & Alkaline test \\
\hline & & Zinc hydrochloride \\
\hline \multirow[t]{2}{*}{6} & \multirow[t]{2}{*}{ Glycosides (saponin) } & General test \\
\hline & & Froth test \\
\hline \multirow[t]{5}{*}{7} & \multirow[t]{5}{*}{ Alkaloids } & Dragendorff's \\
\hline & & Mayer's \\
\hline & & Wagner's \\
\hline & & Hager's \\
\hline & & Tannic acid \\
\hline 8 & $\begin{array}{l}\text { Phenolic compound } \\
\text { (tannins) }\end{array}$ & Chlorgenic acid \\
\hline \multicolumn{3}{|c|}{$\begin{array}{l}\text { Table } 2 \text { Percent } \\
\text { Musa Paradisiaca }\end{array}$} \\
\hline & Content Sample & $\%$ Content \\
\hline & Sugar & 0.57 \\
\hline & Starch & 3.79 \\
\hline & Tannin & 1.29 \\
\hline & Phenolic compound & 4.5 \\
\hline & Flavanoids & 0.35 \\
\hline & Flavonols & 0.64 \\
\hline & Proanthocynidine & 7 \\
\hline
\end{tabular}

Table 3 Shown \% inhibition of alpha-amylase enzyme

\begin{tabular}{llllll}
\hline \multirow{2}{*}{ S.No. } & Extracts & \multicolumn{5}{l}{$\%$ Inhibition } \\
\cline { 3 - 6 } & & $\mathbf{0 . 2}$ & $\mathbf{0 . 4}$ & $\mathbf{0 . 8}$ & I \\
\hline I & Methanol & 20.05 & 36.18 & 71.21 & 74.62 \\
2 & Hydroalcoholic & 28.34 & 48.16 & 82.62 & 84.53 \\
\hline
\end{tabular}

In Vitro - alpha amylase inhibition method.
Here $\mathrm{Ac}=$ absorbance of the control and $\mathrm{As}=$ absorbance of the sample.

\section{Result and discussion}

We identified the content of stem by using various reported test method. This was shown in Table 1. Further, we measured the percentage of different content in methanol extract of stem of MP as shown in Table 2. The inhibitory effect of various concentration of stem was shown the Table $3 \&$ Table 4 . Which indicated both methanol and hydroalcohalic extraction exhibited significant inhibitory effects towards the Alpha-amylase and alpha-glucosidase enzyme. If we increased the concentration then the effect of inhibition enhanced. This indicated that higher concentration of both extract may be required for the treatment of diabetic. In light of the results, our study indicates that both extracts of MP stem have good antidiabetic activity.

$\begin{array}{lllll}\text { Pet. ether } & \text { n-hexane } & \text { Chloroform } & \text { Ethyl acetate } & \text { Methanol } \\ - & + & - & + & - \\ - & + & - & + & - \\ - & - & + & + & - \\ + & + & + & + & - \\ - & + & - & + & - \\ + & + & + & + & + \\ + & + & + & + & ++ \\ - & + & - & - & ++ \\ - & - & + & - & - \\ - & + & - & + & - \\ - & + & - & + & - \\ + & - & + & + & - \\ + & - & + & + & - \\ + & - & + & + & - \\ + & - & + & + & + \\ - & - & + & + & + \\ ++ & + & + & + & +\end{array}$

Table 4 Shown \% inhibition of the alpha-glucosidase enzyme

\begin{tabular}{|c|c|c|c|c|c|}
\hline \multirow[t]{2}{*}{ S.No. } & \multirow[t]{2}{*}{ Extracts } & \multicolumn{4}{|c|}{ \% Inhibition } \\
\hline & & 0.2 & 0.6 & 0.8 & I \\
\hline I & Methanol & 24.3 & 56.26 & 63.81 & 78.17 \\
\hline 2 & Hydroalcoholic & 32.84 & 66.26 & 78.81 & 84.17 \\
\hline
\end{tabular}

In Vitro - alpha-glucosidase inhibition method.

\section{Conclusion}

The present study was performed to investigate the in-vitro antidiabetic activity of methanol and hydroalcoholic extract of stem of MP. Where, we found that phenolic and flavanoids compounds are mostly present in the stem of Musa paradisiacal. The present findings, suggested that both of extracts significantly showed the inhibition towards the both alpha amylase and alpha-glucosidase enzymes (in vitro) in the presence of a dose dependent manner. Besides, hydroalcoholic (water+ethanol) extract was found to be most active against both enzymes. These result revealed that both of extracts may be exhibit significant effect towards the diabetic treatment. 


\section{Acknowledgements}

The authors would like to express their gratitude to Himalayan Institute of Pharmacy and Research Rajawala Dehradun, Uttarakhand.

\section{Conflict of interest}

The author declares no conflict of interest.

\section{References}

1. De Pasquale A. Pharmacognosy the oldest modern science. J Ethnopharmacol. 1984;11(1):1-16.

2. Evans WC, Trease Pharmacognosy. 16th ed. USA: Saunders Elsevier; 2002. $42 \mathrm{p}$.

3. Pradeep K Dutta, Asir K Das, Nilima Benerji. Phytochemistry. 1986;22(11):2563.
4. Olorunfemi AE, Obot S, Jackson U, et al. International Journal of Phytopharmacy Research. 2010;1:21-24.

5. Gupta S, Garg VK, Sharma PK, et al. Analgesic activity of aqueous extract of Musa paradisiaca. Der Pharmacia Sinica. 2011;2(4):74-77.

6. Savali AS, Bhinge SD, Chitapurkar HR. Evaluation of hair growth promoting activity of MP unripe fruit extract. Journal of Natural Pharmaceuticals. 2011;2(3):120-124.

7. Hallikeri CS, Suresh HM, Chandur VK, et al. Anticonvulsant effect of the unripe fruits of MP in albino rats. Phytopharmacology and therapeutic values; 2008. p. 433-438.

8. Swathi D, Jyothi B, Sravanthi C. A Review: Pharmacognostic studies and Pharmacological actions of Musa paradisiaca. International Journal of Innovative Pharmaceutical Research. 2011;2(2):122-125. 